\title{
Optimizing Irrigation and Fertilization of Gardenia jasminoides for Good Growth and Minimal Leaching
}

\author{
Amanda Bayer ${ }^{1}$ \\ Stockbridge School of Agriculture, University of Massachusetts, 210 \\ Bowditch Hall, Amherst, MA 01003
}

John Ruter and Marc W. van Iersel

Department of Horticulture, University of Georgia, 1111 Miller Plant Sciences Building, Athens, GA 30602

Additional index words. nursery production, volumetric water content, electrical conductivity, woody ornamentals, container plants

\begin{abstract}
Excessive irrigation and leaching are of increasing concern in container plant production. It can also necessitate multiple fertilizer applications, which is costly for growers. Our objective was to determine whether fertilizer and irrigation water can be applied more efficiently to reduce leachate volume and nutrient content without negatively impacting aboveground growth of Gardenia jasminoides 'MAGDA I'. Plants were fertilized with one of three rates of a controlled-release fertilizer (subplots) (Florikan 18-6-8, 9-10 month release; $18.0 \mathrm{~N}-2.6 \mathrm{P}-6.6 \mathrm{~K})$ [100 (40 g/plant), $50(20 \mathrm{~g} / \mathrm{plant})$, and $25 \%$ of bag rate $(10 \mathrm{~g} / \mathrm{plant})]$ and grown in 5.4-L containers outside for 137 days. Soil moisture sensor-controlled, automated irrigation was used to provide plants with one of four irrigation volumes (whole plots) (66, 100,132 , or $165 \mathrm{~mL}$ ) at each irrigation event. All plants were irrigated when the control treatment $(66 \mathrm{~mL}$ irrigation volume, $100 \%$ fertilizer treatment) reached a volumetric water content (VWC) of $0.35 \mathrm{~m}^{3} \cdot \mathrm{m}^{-3}$. Plants in the different irrigation treatments were irrigated for $2,3,4$, or 5 minutes, thus applying $66,100,132$, or $165 \mathrm{~mL} /$ plant in the different irrigation treatments. Fertilizer rate had a greater effect on aboveground growth than irrigation volume with the $25 \%$ fertilizer rate resulting in significantly lower shoot dry weight (18.7 g/plant) than the $50 \%$ and $100 \%$ rates (25.3 and $27.3 \mathrm{~g} /$ plant respectively). Growth index was also lowest in the $25 \%$ fertilizer rate. Leachate volume varied greatly during the growing season due to rainfall and irrigation volume effects on leachate were most evident during the third, eighth, and ninth biweekly leachate collections, during which there was minimal or no rainfall. For these collections the control treatment of $66 \mathrm{~mL}$ resulted in minimal leachate (less than $130 \mathrm{~mL}$ over the 2-week leachate collection period), whereas leachate volume increased with increasing irrigation volumes. Pore water electrical conductivity (EC), leachate $\mathrm{EC}, \mathrm{NO}_{3}-\mathrm{N}$ content, and $\mathrm{PO}_{4}-\mathrm{P}$ content were all highest with the $100 \%$ fertilizer rate, with the $66 \mathrm{~mL}$ irrigation treatment having the highest leachate $\mathrm{EC}$ for all fertilizer treatments. Cumulative leachate volumes for the 66 and $100 \mathrm{~mL}$ irrigation treatments were unaffected by fertilizer rate, whereas the 132 and $165 \mathrm{~mL}$ had greater leaching at the $25 \%$ fertilizer rate. Lower irrigation volumes resulted in reduced water and nutrient leaching and higher leachate EC. The higher leachate EC was the result of higher concentration of nutrients in less volume of leachate. The results of this study suggest that a combination of reduced fertilizer rates (up to $50 \%$ ) and more efficient irrigation can be used to produce salable plants with reduced leaching and thus less environmental impact.
\end{abstract}

Improving water and nutrient management in container plant production will help the nursery industry adapt to decreasing

\footnotetext{
Received for publication 26 Nov. 2014. Accepted for publication 2 May 2015.

The research was funded by USDA-NIFA-SCRI (award no. 2009-51181-05768)

We thank Sue Dove, Kevin Whitaker, Faustine Sonon, and Kengelle Chukwurah for their help with this research and McCorkle Nurseries for donating the plant material and for supplying substrate. We thank Bob Teskey, Matthew Chappell, and Sheryl Wells for their suggestions on this manuscript. We thank the University of Georgia Statistical Consulting Center for their advice in statistical analysis.

${ }^{1}$ To whom reprint requests should be addressed; e-mail abayer10@umass.edu.
}

water resources and comply with the growing number of laws and regulations regarding nursery water use, fertilizer applications, and nutrient levels in runoff (Beeson et al., 2004; Chappell et al., 2013a). Overirrigation commonly occurs for many reasons, including the belief that maintaining substrates near container capacity is necessary for maximum growth (Beeson, 2006), inefficiencies in irrigation application and poor uniformity of irrigation systems (Fare et al., 1992), and the grower preference to over-rather than under - apply water (Million et al., 2007; Yeager et al., 2010). Also, many growers apply large amounts of fertilizer out of concern that lower fertilizer applications could negatively impact growth (Owen et al., 2008; Tyler et al., 1996). The combination of excessive irrigation and high fertilizer rates often leads to significant leaching of fertilizers, which has a negative environmental impact as the leachate enters local ecosystems (Lea-Cox and Ross, 2001), and can lead to the need for additional fertilizer applications late in the production cycle.

Best management practices (BMPs) have been adopted by many growers in an effort to irrigate and fertilize more efficiently. Cyclic irrigation, which applies daily irrigation via multiple smaller applications, can be used to apply reduced irrigation volumes, and can reduce water and nutrient leaching (Fare et al., 1994; Ruter, 1998). Other BMPs for irrigation management include grouping plants by water requirements and inspecting irrigation systems for uniformity (Chappell et al., 2013a). More recently, soil moisture sensor-automated irrigation has been used to control irrigation with a variety of nursery and greenhouse crops, including Hibiscus acetosella (Bayer et al., 2013), Lantana camara (Bayer et al., 2014), Hydrangea macrophylla (van Iersel et al., 2009), Gaura lindheimeri (Burnett and van Iersel, 2008), and G. jasminoides (Chappell et al., 2013b). Until recently most sensor-controlled irrigation has been for research purposes; however, wireless sensor networks capable of controlling irrigation are being developed for implementation in commercial production (Kohanbash et al., 2013; Lea-Cox et al., 2013).

Fertilization and nutrient leaching BMPs have also been adopted, including using controlled-release fertilizers that last throughout the production period and monitoring substrate nutrient levels (Yeager et al., 2010). Less leaching can help reduce nutrient runoff, but there is concern that this may result in the buildup of salts in the substrate, which can damage roots (Bilderback, 2002). Irrigating to maintain a moderate or high leaching fraction (volume of water leached/ volume of water applied) is commonly used to avoid fertilizer salt buildup in substrates. Monitoring EC can ensure that salt levels do not become excessive. The pour-through method of EC measurement is commonly used by growers (Bilderback, 2002; Chappell et al., 2013a). This method produces reliable results, but is labor intensive and can be inconvenient if samples are sent to a laboratory for analysis. In situ methods are instantaneous and provide continuous measurements allowing for a clearer picture of the impact of fertilization and irrigation, but most sensors measure the bulk EC of the soil or substrate, which is a combination of substrate/soil particles, air spaces, and substrate/soil solution. Substrate bulk EC depends on substrate water content (Scoggins and van Iersel, 2006) and is not a reliable measurement of nutrient levels in the substrate. New sensors, which measure the bulk dielectric, temperature, and bulk EC (GS3; Decagon Devices, Pullman, WA), can be used to estimate pore water EC using the Hilhorst model (Hilhorst, 2000; van Iersel et al., 2013). These sensors are affordable and provide real-time information about the growing conditions that can be used on 
a day-to-day basis to make irrigation and fertilization decisions.

The effects of reduced fertilizer rates and irrigation application have been examined (Fare et al., 1994; Million et al., 2007; Owen et al., 2008; Tyler et al., 1996); however, the effects of reduced irrigation volume based on plant water use and fertilizer rate have not been adequately studied. Using soil moisture sensors to irrigate based on substrate water content allows for efficient irrigation based on plant water use. The effect of sensorcontrolled irrigation along with reduced fertilizer application rates on plant growth and leaching will provide further information about the potential for reducing fertilizer inputs with efficient irrigation. Our objective was to determine if fertilizer rate and irrigation volume could be applied more efficiently to reduce leachate volume and leachate nutrient content without negatively impacting growth of $G$. jasminoides 'MAGDA I'. Our hypothesis was that more efficient irrigation can be combined with reduced fertilizer inputs to reduce leaching and nutrient levels in leachate without impacting plant growth; with reduced leaching, more fertilizer remains in the container and available to the plant.

\section{Materials and Methods}

Plant material. The experiment was conducted outdoors at the University of Georgia horticulture farm in Watkinsville, GA, from
27 Apr. to 8 Nov. 2012. Rooted cuttings of $G$. jasminoides 'MADGA I' (PP number 19988) Heaven Scent ${ }^{\circledR}$ were obtained from McCorkle Nurseries (Dearing, GA). Rooted cuttings were planted in 5.4-L black plastic containers filled with a pine bark substrate $(100 \%)$ amended with $1.97 \mathrm{~kg} \cdot \mathrm{m}^{-3}$ dolomitic lime, $0.74 \mathrm{~kg} \cdot \mathrm{m}^{-3}$ Micromax (Everris, Dublin, OH), and 0.74 $\mathrm{kg} \cdot \mathrm{m}^{-3}$ gypsum. Substrate physical properties were as described by O'Meara et al. (2014). On 1 May, controlled-release fertilizer (Florikan 18-6-8, 9-10 month release; $18.0 \mathrm{~N}-2.6 \mathrm{P}-$ 6.6K; Florikan ESA LLC, Sarasota, FL) was incorporated into the top $15 \mathrm{~cm}$ of the substrate. The nitrogen $(\mathrm{N})$ in the fertilizer was $9.4 \%$ from $\mathrm{NO}_{3}-\mathrm{N}$ and $8.6 \%$ from $\mathrm{NH}_{4}-\mathrm{N}$. Nitrogen and phosphorus (P) sources included ammonium nitrate, potassium nitrate, ammonium phosphate, and calcium phosphate, which were polymer coated to provide $16.2 \%$ slowrelease $\mathrm{N}, 4.95 \%$ slow-release available $\mathrm{P}$, and $7.2 \%$ slow-release soluble potash. After fertilizer treatment applications, plants were kept well watered (above a $\theta$ threshold of 0.40 $\mathrm{m}^{3} \cdot \mathrm{m}^{-3}$ ) for 8 weeks to allow for root establishment before initiating irrigation treatments on 25 June.

Treatments and data collection. Treatment combinations included three fertilizer rates (subplots) of $100 \%$ (40 g/plant), $50 \%$ ( $20 \mathrm{~g} /$ plant $)$, and $25 \%$ of bag rate $(10 \mathrm{~g} /$ plant $)$ and four irrigation volumes (whole plots) of $66,100,132$, or $165 \mathrm{~mL}$ per irrigation event for a total of 12 treatment combinations. There were four irrigation lines per block to apply each of the four irrigation volume treatments. Four plants receiving each fertilizer rate were on each irrigation line for a total of 12 plants per irrigation line and 48 plants per block (Fig. 1). Irrigation was controlled using a soil moisture sensor automated irrigation system similar to that described by Nemali and van Iersel (2006). Soil moisture sensors (10HS; Decagon Devices) were inserted into two pots, receiving the $100 \%$ fertilizer rate for each irrigation line for a total of eight sensors per block and 32 total. Sensors were inserted from the top at a $45^{\circ}$ angle close to the center of the pot so that the entire sensor was in the substrate. Thirty-two sensors were connected to a multiplexer (AM416; Campbell Scientific, Logan, UT) which was connected to a datalogger (CR10; Campbell Scientific). The datalogger measured sensor voltage output every $20 \mathrm{~min}$. The voltage readings from the sensors were converted into VWC $(\theta)$ using our own calibration $[\theta=-0.4009+1.0124 \times$ output (V)] using the method described by Nemali et al. (2007). When both sensors in the same experimental unit $(100 \%$ fertilizer, $66 \mathrm{~mL}$ irrigation treatment) were below the $\theta$ threshold of $0.35 \mathrm{~m}^{3} \cdot \mathrm{m}^{-3}$, the datalogger signaled the relay driver (SDM16AC/DC controller; Campbell Scientific) to open all four solenoid valves (sprinkler valve; Orbit, Bountiful, UT) in a block to apply irrigation to all four irrigation treatments. The $66 \mathrm{~mL}$ irrigation volume, $0.35 \mathrm{~m}^{3} \cdot \mathrm{m}^{-3} \theta$ threshold irrigation control was based on previous irrigation

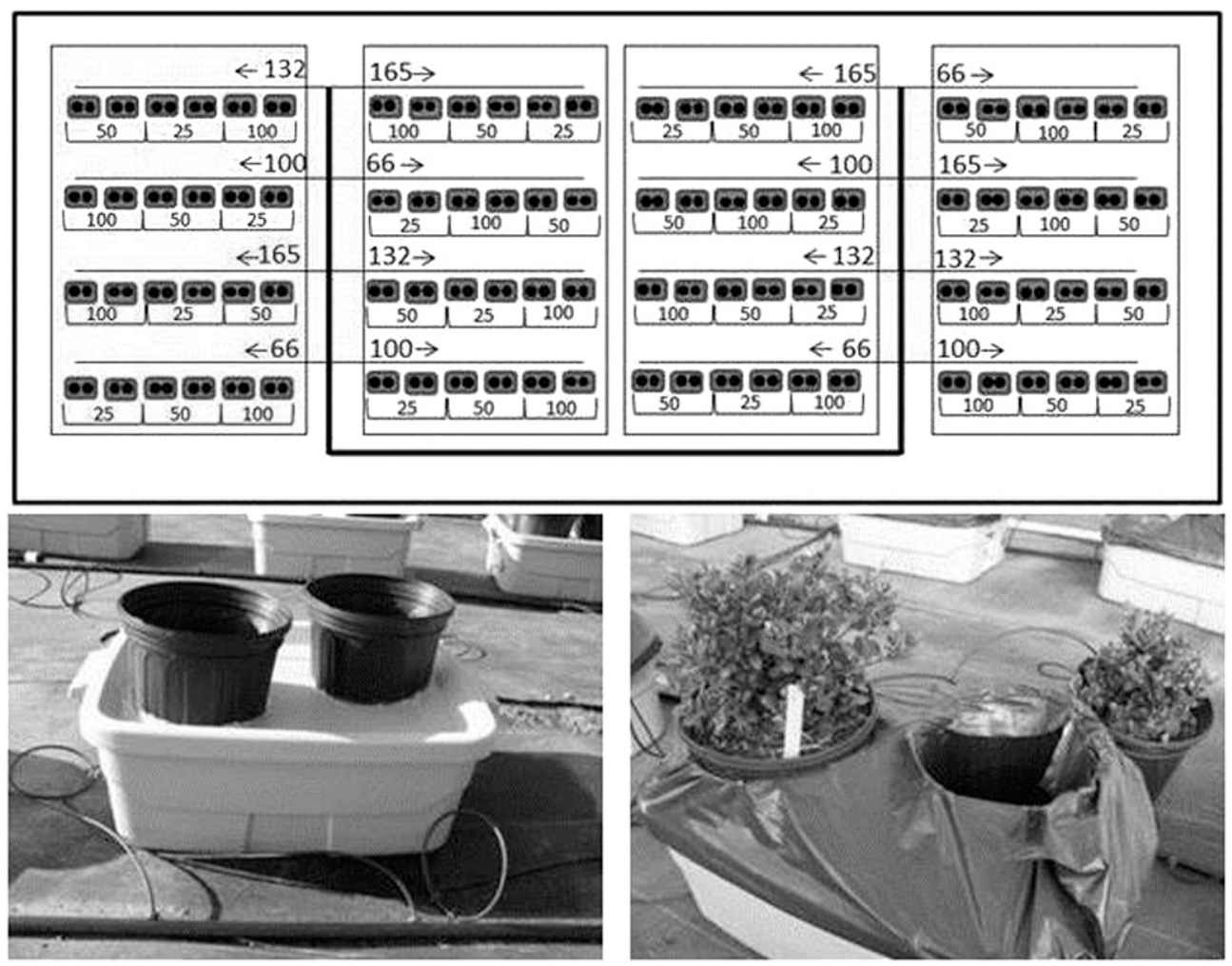

Fig. 1. Experiment layout and setup for leachate collection/rainfall exclusion. The experiment was setup as a split plot with four replications. Main plots are irrigation volume treatments $(66,100,132$, and $165 \mathrm{~mL})$ and split plots were fertilizer rates $(25 \%, 50 \%$, and $100 \%$ of bag rate). Two $5.4-\mathrm{L}$ pots were secured into the lid of a 38-L tub and a trash bag with slits was placed over these two pots and a second 5.4-L pot containing a plant was placed in each pot, allowing leachate and rainfall that moved through the substrate to be collected in the $38-\mathrm{L}$ tub. 
control research and provides a high $\theta$ with minimal leaching. At the $0.35 \mathrm{~m}^{3} \cdot \mathrm{m}^{-3}$ threshold, the substrate matric potential was -6.3 $\mathrm{kPa}$. Plants in the different irrigation treatments were irrigated for $2,3,4$, or $5 \mathrm{~min}$ using dribble rings (Dramm, Manitowoc, WI) connected to pressure-compensated drip emitters (Netafim USA, Fresno, CA), thus applying $66,100,132$, or $165 \mathrm{~mL} /$ plant in the different irrigation treatments. All plots within a replication were watered the same number of times, but for different duration to apply the different irrigation rates.

The soil moisture readings recorded every $20 \mathrm{~min}$ from each sensor were averaged and stored every $2 \mathrm{~h}$ and the number of irrigation events in each replication was recorded daily. The daily and total irrigation volume for a plot was calculated from the number of irrigation events and the volume of water applied per irrigation event. Twenty-four GS3 soil moisture, temperature, and EC sensors (Decagon Devices) connected to five data loggers (EM50; Decagon Devices) were installed in one plant per treatment for two blocks. Sensors were installed by cutting a slit in the north side of the container and inserting the sensor into the substrate. Data from the GS3 sensors were used to calculate solution (pore water) EC, using the Hilhorst model with an offset of 4.1 (Hilhorst, 2000).

Two 5.4-L containers identical to the containers with plants were secured into the lid of a 38-L tub (Fig. 1) in which leachate was collected. The containers with plants were placed into the secured containers. Trash bags were placed over the collection tub before the pots containing plants were inserted to exclude rainwater from the collection tub so that only rainwater that had moved through the pot and substrate was included in the leachate. Two leachate tubs (with four total plants) were considered an experimental unit. Measurements for the four plants in an experimental unit were averaged, and leachate for the two tubs in an experimental unit was combined for measurement. Plant height and width as well as temperature-compensated leachate volume and EC (Twin Conductivity Tester; Horiba, Irvine, CA) were measured biweekly. A leachate sample was also collected biweekly for later $\mathrm{NO}_{3}^{-}$and $\mathrm{PO}_{4}^{-}$analysis. Samples were stored frozen at $-9{ }^{\circ} \mathrm{C}$ until $\mathrm{NO}_{3}{ }^{-}$and $\mathrm{PO}_{4}^{-}$analyses were conducted at room temperature. $\mathrm{NO}_{3}^{-}$was analyzed using an ion-selective electrode (Cole-Parmer Combination Ion Selective Electrode; Cole-Parmer, Vernon Hills, IL). Phosphate $\left(\mathrm{PO}_{4}^{-}\right)$analysis was conducted at the University of Georgia Soil, Plant, and Water Analysis Laboratory (2400 College Station Road, University of Georgia, Athens, GA) using the continuous flow colorimetric method (U.S. Environmental Protection Agency, 1983). Only $\mathrm{NO}_{3}-\mathrm{N}$ was measured, because the amount of $\mathrm{NO}_{3}-\mathrm{N}$ in leachate is greater than $\mathrm{NH}_{4}-\mathrm{N}$ due to nitrification in the substrate (Niemiera and Leda, 1993). Niemiera and Leda (1993) reported $\mathrm{NO}_{3}-\mathrm{N}$ was $92 \%$ of the total $\mathrm{N}$ in leachate from a fertilizer that was $41 \% \mathrm{NO}_{3}-\mathrm{N}$ and $59 \% \mathrm{NH}_{4}-\mathrm{N}$. Irrigation volumes and rainfall were measured daily throughout the experiment. At the conclusion of the 137-d experiment shoots were cut off at the substrate surface and dried at $80^{\circ} \mathrm{C}$, after which dry weight was determined. Compactness was calculated as shoot dry mass per unit plant height. Growth index was calculated as (height + width $1+$ width 2$) / 3$. Environmental conditions were measured using a temperature and relative humidity sensor (HMP50; Vaisala, Woburn, MA), a quantum sensor (SQ-110; Apogee Instruments, Logan, UT), and a rain gauge (ECRN-100; Decagon Devices) connected to the datalogger. Rainfall volume per plant was calculated as rain amount $\times$ pot surface, ignoring any potential effects of the canopy on rainfall capture.

Experimental design and data analysis. The experimental design was a split plot with four replications with main plots being irrigation treatments and splits being fertilizer rates. Each experimental unit consisted of four plants. Data that were collected multiple times throughout the experiment were analyzed by collection period. Data were analyzed using the PROC MIXED procedure of SAS (SAS Version 9.2; SAS Institute, Cary, NC), with $P \leq 0.05$ considered to be statistically significant. Treatment means were separated using either the SLICE or PDIFF option of PROC MIXED. PDIFF was used to look at main effects of the LS-means and SLICE was used for analysis for the LSmeans of interactions. Curve fitting was done using SigmaPlot (Systat, San Jose, CA).

\section{Results and Discussion}

Irrigation and leachate. Cumulative irrigation volumes were $6.6,10.0,13.2$, and 16.5 $\mathrm{L} /$ plant in the $66,100,132$, and $165 \mathrm{~mL}$ irrigation treatments, respectively (Fig. 2A). Including rainfall, each plant received 20.9, $24.3,27.5$, and $30.8 \mathrm{~L}$ of water during the study in the $66,100,132$, and $165 \mathrm{~mL}$ irrigation treatments, respectively. The number of irrigation events varied on a biweekly basis because of differences in biweekly rainfall (Fig. 3A). Rainfall increased VWC, and reduced the need for irrigation (Fig. 3B). For example, high rainfall during the second biweekly leachate collection period resulted in only one irrigation events and each plant received only 0.03 to $0.08 \mathrm{~L}$ of water from irrigation (biweekly irrigation volume data not shown). In contrast, during the last biweekly leachate collection period there was no rain, 14 irrigation events, and total biweekly irrigation volume ranged from 0.9 to $2.3 \mathrm{~L} /$ plant (biweekly irrigation data not shown).

Leachate volume differed among the various collection periods $(P<0.001)$ due to rainfall. For example, the large amount of rain during the second leachate collection period resulted in similar leachate volumes

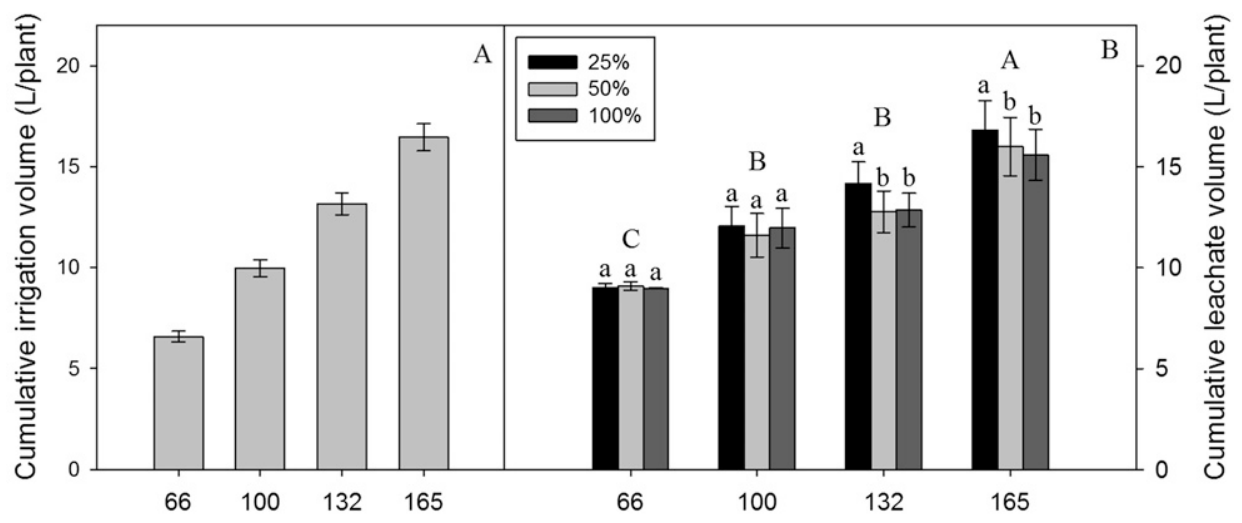

Irrigation volume (mL/irrigation event)

Fig. 2. Cumulative irrigation volume, excluding rainfall, (A) and cumulative leachate volume (B) to produce Gardenia jasminoides 'MAGDA I'. Irrigation was initiated for all treatments when the volumetric water content of the control $(66 \mathrm{~mL}$ irrigation volume, $100 \%$ fertilizer rate $)$ dropped below the $0.35 \mathrm{~m}^{3} \cdot \mathrm{m}^{-3}$ threshold. Irrigation was applied for 2, 3, 4, or $5 \mathrm{~min}$, applying 66, 100, 132, and $165 \mathrm{~mL}$ of irrigation water to the different treatments. Fertilizer rates were applied at $100 \%, 50 \%$, and $25 \%$ of bag rate of a controlled-release fertilizer. Irrigation treatment main effects are indicated by capital letters. Means within an irrigation treatment with a different lower case letter indicate different cumulative leachate volumes for each fertilizer rate $(P<0.05)$. Error bars indicate sEs. 
for all irrigation treatments (Fig. 3A), because most of the leachate was the result of rainfall. Leachate volume increased with increasing irrigation volume $(P<0.0001)$ for all but the second collection period $(P<$ $0.0005)$. Irrigation treatment effects on leachate are the most evident during the third, eighth, and ninth collection periods, during which rainfall was less than $20 \mathrm{~mm}$. For these collections, the $66 \mathrm{~mL}$ irrigation volume (averaged over fertilizer rates) resulted in 126,59 , and $12 \mathrm{~mL}$ of leachate for the third, eighth, and ninth collection periods, respectively compared with 802,650 , and $753 \mathrm{~mL}$ with the $165 \mathrm{~mL}$ irrigation volume (Fig. 3A). The low leaching shows that efficient irrigation can be used to produce little leachate in the absence of rain.

Increasing the irrigation volume from 66 to $165 \mathrm{~mL}$ increased the cumulative leachate volume from 9.0 to $15.2 \mathrm{~L}$ (Fig. 2B). The effect of fertilizer rate on cumulative leachate volume differed for the irrigation treatments $(P=0.0062)$, with no fertilizer effect in

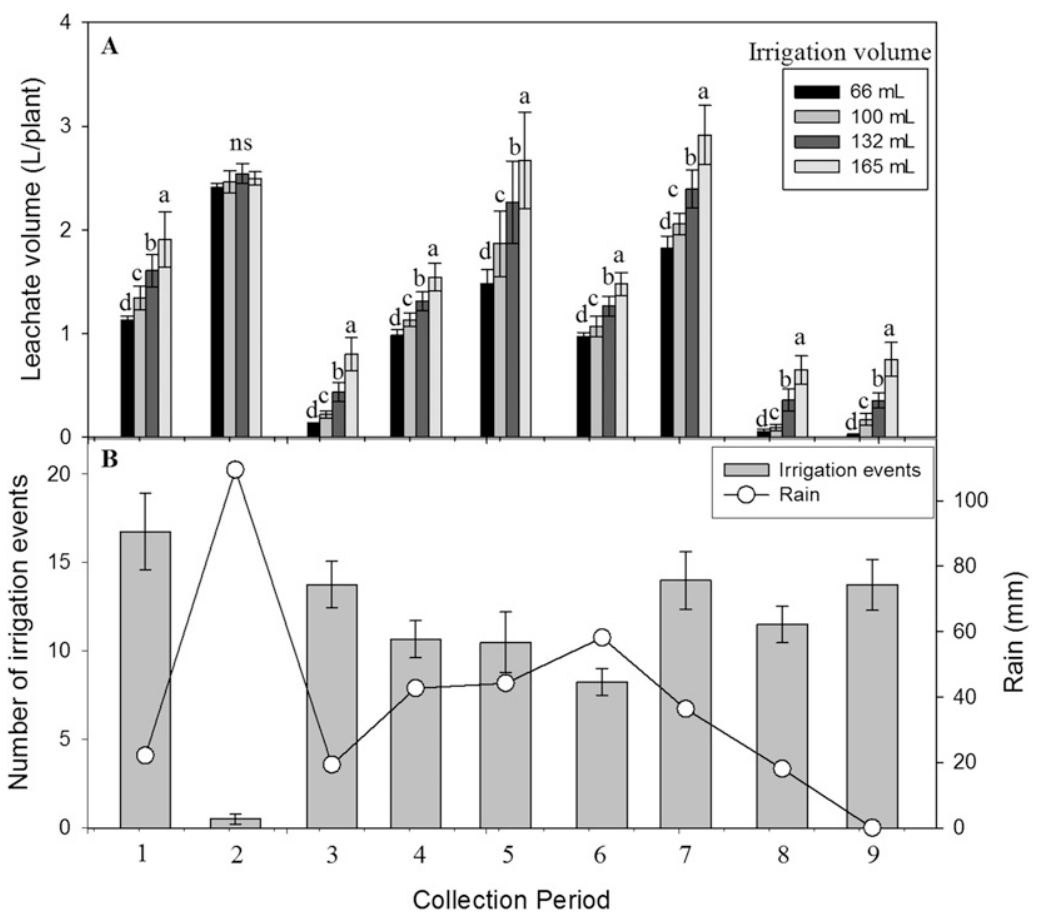

Fig. 3. Biweekly leachate volume (A), rainfall, and number of irrigation events (B) to produce Gardenia jasminoides 'MAGDA I'. Biweekly leachate volume was averaged over fertilizer treatments because of nonsignificant fertilizer rate effects. Irrigation was initiated for all treatments when the volumetric water content of the control ( $66 \mathrm{~mL}$ irrigation volume, $100 \%$ fertilizer rate) dropped below the 0.35 $\mathrm{m}^{3} \cdot \mathrm{m}^{-3}$ threshold. Irrigation was applied for $2,3,4$, or $5 \mathrm{~min}$, applying $66,100,132$, and $165 \mathrm{~mL}$ of irrigation water to the different treatments over the course of the 137-d study. Means within a collection period with different letters indicate different leachate volumes, ns indicates no irrigation volume effect on leachate volume $(P<0.05)$. Error bars indicate SES. the 66 and $100 \mathrm{~mL}$ irrigation treatments. For the 132 and $165 \mathrm{~mL}$ irrigation treatments the $25 \%$ fertilizer treatment resulted in more leachate than the $50 \%$ and $100 \%$ treatments. The shoot dry weight of plants in the $25 \%$ fertilizer treatment was less than other fertilizer treatments (Fig. 4A), which could have resulted in reduced water use and increased leaching. Leachate volume differed among irrigation volume $(P=0.0013)$ with the 100 and $132 \mathrm{~mL}$ treatment resulting in similar leachate volumes.

Our results showed no effect of fertilizer rate on biweekly leachate collection volume and fertilizer rate only altered cumulative leachate volume in the 132 and $165 \mathrm{~mL}$ irrigation volume treatments. Fare et al. (1994) found that fertilizer treatment had no effect on leachate volume from Ilex crenata 'Compacta'. Similar to this study, leachate volume of $L$. camara 'Sunny Side Up' increased with increasing irrigation duration, regardless of fertilizer rate $(25 \%$ to $150 \%$ of the labeled rate of $17.71 \mathrm{~g} /$ plant) (Bayer et al., 2014). Runoff volume was reduced by $66 \%$ to $79 \%$ by replacing the amount of water used on a daily basis, compared with applying $19 \mathrm{~mm} \cdot \mathrm{d}^{-1}$, considered to be the standard industry practice (Warsaw et al., 2009). During leachate collection periods with minimal rainfall we found that leachate volume on average increased by $91 \%$ as irrigation volume increased from 66 to $165 \mathrm{~mL}$. Reducing irrigation volume of $I$. crenata 'Compacta' from 13 to $8 \mathrm{~mm} \cdot \mathrm{d}^{-1}$ reduced leachate by around 50\% (Fare et al., 1994). Cyclic irrigation reduced leachate volume from I. crenata 'Compacta' by $50 \%$ (Fare et al., 1994) and from Prunus ×incamp 'Okame' by 34\% (Ruter, 1998). Runoff from Viburnum odoratissimum was more than doubled with increased irrigation volume from 1 to $2 \mathrm{~cm}$ daily irrigation, whereas fertilizer rate (15 or $30 \mathrm{~g} / \mathrm{plant}$ ) did not affect runoff volume (Million et al., 2007). Cumulative leachate volume of $C$. dammeri 'Skogholm' was decreased by $63 \%$ by maintaining a low $(0.0-0.2)$ instead of high leaching fraction $(0.4-0.6)$

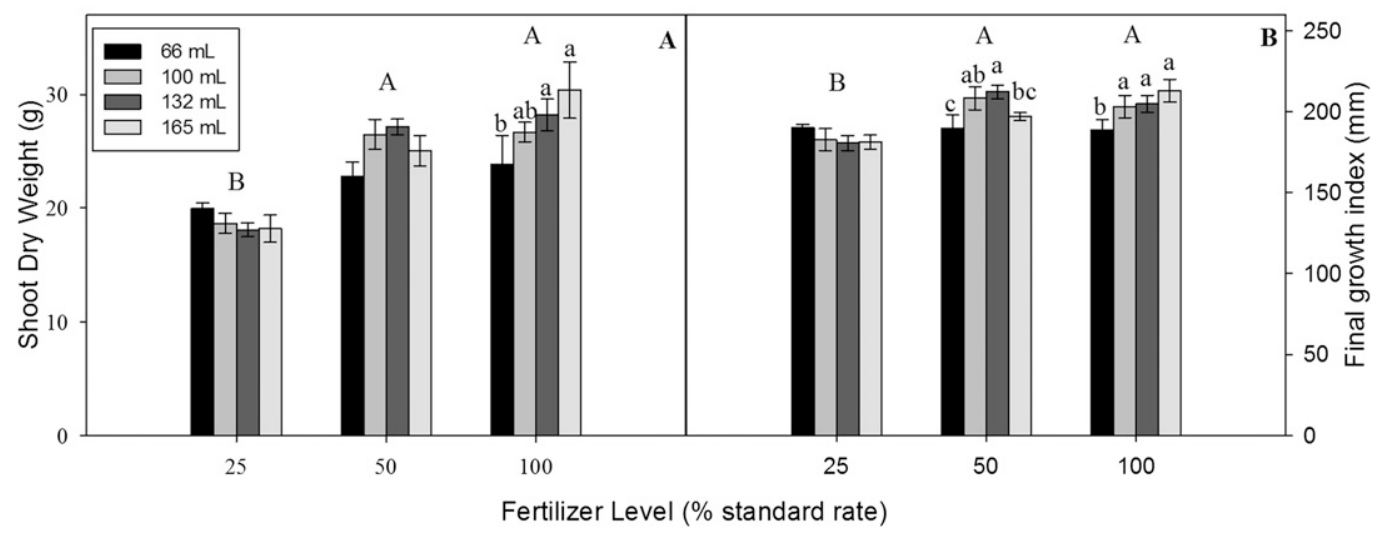

Fig. 4. Shoot dry weight (A) and final growth index (B) of Gardenia jasminoides 'MAGDA I'. Irrigation was initiated for all treatments when the volumetric water content of the control ( $66 \mathrm{~mL}$ irrigation volume, $100 \%$ fertilizer rate) dropped below the $0.35 \mathrm{~m}^{3} \cdot \mathrm{m}^{-3}$ threshold. Irrigation was applied for $2,3,4$, or $5 \mathrm{~min}$, applying $66,100,132$, and $165 \mathrm{~mL}$ of irrigation water to the different treatments. Fertilizer rates were applied at $100 \%, 50 \%$, and $25 \%$ of bag rate of a controlled-release fertilizer. Upper case letters indicate fertilizer main effects and lower case letters indicate irrigation effects within a fertilizer level $(P<$ 0.05). Error bars indicate SES. 
with no effect of $50 \%$ reduced fertilizer rate on leachate volume (Tyler et al., 1996). The results reported by all of these researchers were similar to our results in that fertilizer rate has no or minimal effect on leachate volume and that greater irrigation volumes result in higher leachate volumes.

For leachate EC, the fertilizer rate by irrigation volume by collection period interaction was not significant. Fertilizer rate by collection period $(P<0.0001$; Fig. 5A), irrigation volume by collection period $(P<$ 0.0001 ; Fig. $5 \mathrm{~B})$, and fertilizer rate by irrigation volume interactions $(P<0.04$; Fig. $5 \mathrm{C})$, were all significant. Irrigation volume and fertilizer rate effects differed among collection periods, because of variable rainfall, which affected the leachate volume and thus the dilution of the leached salts (Fig. 3B). Leachate EC decreased from 21 Aug. until the end of the study (Fig. 5A and B), likely because of a combination of a decrease in the remaining fertilizer to be leached and more efficient nutrient capture of larger root systems as the experiment progressed. Leachate EC was low $\left(0.11-0.31 \mathrm{dS} \cdot \mathrm{m}^{-1}\right)$ during the ninth collection period (17-31 Oct.), suggesting that the applied fertilizer may have been largely depleted. With an average high air temperature of $29^{\circ} \mathrm{C}$ during the study, the fertilizer had an expected release period of 9 months. However, June through August had an average high temperature of $32{ }^{\circ} \mathrm{C}$, with $38 \mathrm{~d}$ above $32{ }^{\circ} \mathrm{C}$, which could have contributed to the fertilizer being released more quickly. Substrate temperatures of container grown plants in the southeastern United States have been reported to be as high as $57{ }^{\circ} \mathrm{C}$ (Martin and Ingram, 1991) with substrate temperature higher than air temperature (Ruter, 1993). High rainfall volumes could have also resulted in increased diffusion of fertilizer from the prills.

The large amount of rain during the second collection period (10-24 July) apparently leached out much of the released nutrients, resulting in low leachate EC during the third collection period (24 July-8 Aug.). Averaged overall collection periods, the $66 \mathrm{~mL}$ irrigation volume resulted in higher leachate EC than larger irrigation volumes (Fig. 5B), likely because of lower leachate volumes (Fig. 3A) resulting in less dilution and thus higher nutrient concentrations. Irrigation volume did not affect leachate EC at the $25 \%$ fertilizer rate during any collection period (Fig. 5C), likely because the low fertilizer rate resulted in low leachate EC regardless of irrigation volume.

The effect of fertilizer rate on pore water EC varied by leachate collection period $(P<$ $0.0001)$. Pore water EC was highest at the $100 \%$ fertilizer rate $(P<0.0001)$. During the second collection period (10-23 July), with $110 \mathrm{~mL}$ of rain, the impact of rainfall can be seen in the rapid increases in pore water EC and VWC (Fig. 6A and C; data not shown for the 66,132 , and $165 \mathrm{~mL}$ irrigation treatments). During the ninth collection period (17-31 Oct.), with no rain, the depletion of fertilizer is reflected in the low pore water
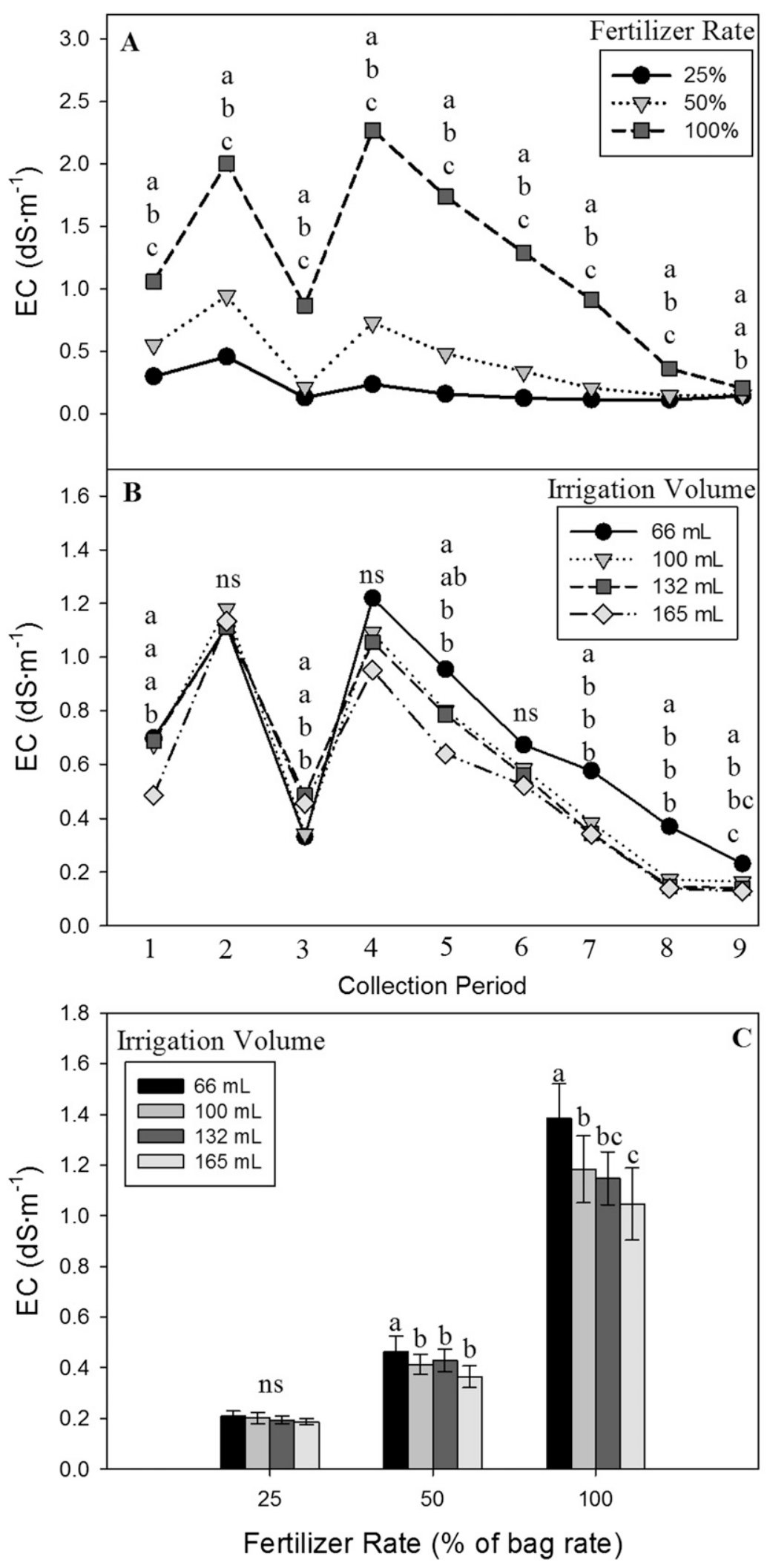

Fig. 5. Leachate electrical conductivity (EC) for the nine biweekly collection periods to produce Gardenia jasminoides 'MAGDA I' as affected by fertilizer rate (A) and irrigation volume (B). Average leachate EC for the 12 fertilizer rate by irrigation volume treatment combinations $(\mathbf{C})$. Irrigation was initiated for all treatments when the volumetric water content of the control $(66 \mathrm{~mL}$ irrigation volume, $100 \%$ fertilizer rate) dropped below the $0.35 \mathrm{~m}^{3} \cdot \mathrm{m}^{-3}$ threshold. Irrigation was applied for $2,3,4$, or $5 \mathrm{~min}$, applying $66,100,132$, and $165 \mathrm{~mL}$ of irrigation water to the different treatments. Fertilizer rates were applied at $100 \%, 50 \%$, and $25 \%$ of bag rate of a controlled-release fertilizer. For graphs $\mathbf{A}$ and $\mathbf{B}$, letters indicate mean separation within a collection period for fertilizer rate and irrigation volume, respectively. For graph $\mathbf{C}$, letters indicate significant irrigation volume effects within a fertilizer rate. NS indicates no significant effect on leachate EC for all graphs. Error bars indicate SES. 


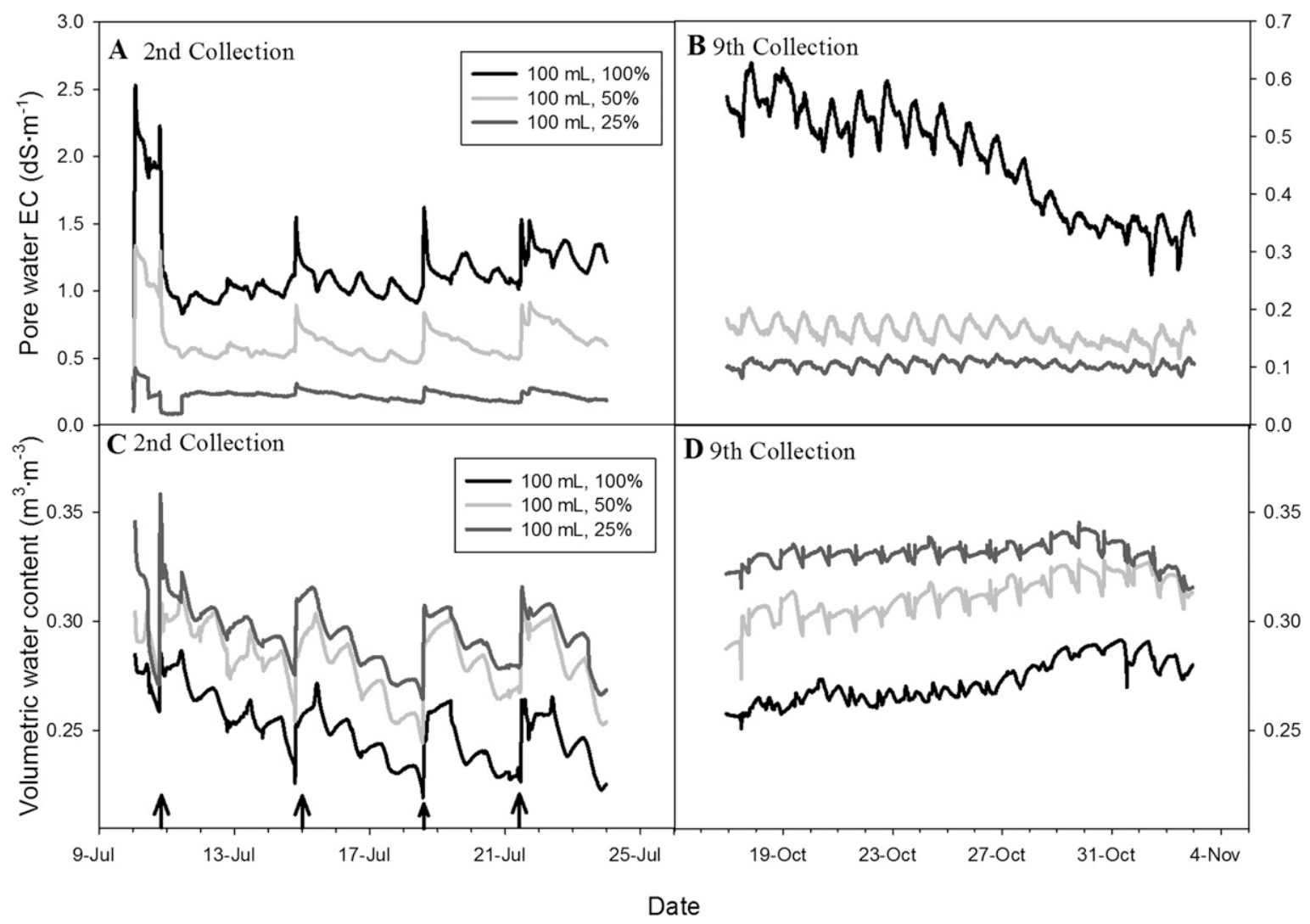

Fig. 6. Pore water electrical conductivity and substrate water content for the $100 \mathrm{~mL}$ irrigation volume treatment during the second collection period (A and $\mathbf{C})$ and ninth collection period (B and $\mathbf{D}$ ) during the production of Gardenia jasminoides 'MAGDA I'. Note the different $y$-axis scales in $\mathbf{A}$ and $\mathbf{B}$. Fertilizer rates were applied at $100 \%, 50 \%$, and $25 \%$ of bag rate of a controlled-release fertilizer. For the second collection period, arrows indicate rainfall events of $650,145,99$, and $175 \mathrm{~mm}$ on $10,14,18$, and 21 July, respectively. There was no rainfall during the ninth collection period.

EC, with EC below $0.2 \mathrm{dS} \cdot \mathrm{m}^{-1}$ for all but the $100 \%$ fertilizer treatments (Fig. 6B and D). A decrease in pore water $\mathrm{EC}$ for the $100 \%$ fertilizer rate occurs over the 2-week period. Pore water EC and leachate EC followed similar magnitude responses during the various leachate collection periods. For example, both pore water and leachate EC decreased from the second to the third collection period and then increased from the third to the fourth collection period. After the fourth collection period there was a general decreasing trend for both pore water and leachate EC. There was a trend of decreasing pore water EC with decreasing fertilizer rate and increasing irrigation volume (data not shown). At the $25 \%$ fertilizer rate, average pore water EC was greatest during the second collection period $\left(0.3 \mathrm{dS} \cdot \mathrm{m}^{-1}\right)$, and decreased from 0.2 to $0.1 \mathrm{dS} \cdot \mathrm{m}^{-1}$ from the fourth to ninth collection period. At the $100 \%$ fertilizer rate, average pore water EC was greatest during the second and fourth collection periods $\left(1.5 \mathrm{dS} \cdot \mathrm{m}^{-1}\right)$ and decreased from the fourth to ninth collection periods from 1.5 to $0.5 \mathrm{dS} \cdot \mathrm{m}^{-1}$.

The quantity of $\mathrm{NO}_{3}-\mathrm{N}$ and $\mathrm{PO}_{4}-\mathrm{P}$ leached varied by collection period in a pattern similar to leachate EC, but was unaffected by irrigation volume (Fig. 7). Increasing irrigation volume resulted in more leachate and diluted the leached nutrients, without an effect on the quantity of nutrients leached. The amount of $\mathrm{NO}_{3}-\mathrm{N}$ and $\mathrm{PO}_{4}-\mathrm{P}$ leached increased with fertilizer rate for all but the third, eighth, and ninth collection periods. For the third collection period, quantities are low likely because of the large amount of nutrients leached due to rainfall during the second collection period. For the eighth and ninth collections, quantities likely are low as fertilizer has been used or leached as the experiment progressed as seen by the reduction in pore water $\mathrm{EC}$ at the end of the study. The quantity of $\mathrm{NO}_{3}-\mathrm{N}$ leached was $44 \%$ to $81 \%$ less for the $50 \%$ fertilizer treatment and $69 \%$ to $92 \%$ less for the $25 \%$ treatment compared with the $100 \%$ fertilizer treatment depending on collection period. The quantity of $\mathrm{PO}_{4}-\mathrm{P}$ leached was $35 \%$ to $81 \%$ and $43 \%$ to $92 \%$ less than the $100 \%$ fertilizer treatment for the $50 \%$ and $25 \%$ fertilizer treatments, respectively.

In contrast to our results, other researchers did find an effect of irrigation on nutrient leaching. $\mathrm{NO}_{3}-\mathrm{N}$ quantities in the leachate were reduced by an average of $38 \%$ and $59 \%$ for the $100 \%$ and $75 \%$ daily water use (DWU) irrigation treatments compared with the control of $19 \mathrm{~mm} \cdot \mathrm{d}^{-1}$ (Warsaw et al., 2009). The $100 \%$ and $75 \%$ DWU treatments resulted in $46 \%$ and $74 \%$ reduced losses in $\mathrm{PO}_{4}-\mathrm{P}$ than the control. $\mathrm{NO}_{3}-\mathrm{N}$ and $\mathrm{PO}_{4}-\mathrm{P}$ quantities in effluent were higher for the high fertilizer rate (3.5 $\mathrm{g} \mathrm{N} /$ container) at both high and low leaching fractions, with low leaching fraction reducing $\mathrm{NO}_{3}-\mathrm{N}$ quantity by $66 \%$ and $\mathrm{PO}_{4}-\mathrm{P}$ by $57 \%$ (Tyler et al., 1996). Increasing irrigation rate from 1 to $2 \mathrm{~cm} \cdot \mathrm{d}^{-1}$ increased $\mathrm{NO}_{3}-\mathrm{N}$ and $\mathrm{PO}_{4}-\mathrm{P}$ losses by $21 \%$ and $28 \%$ at the high fertilizer rate $(30$ $\mathrm{g} /$ container) and by $34 \%$ and $38 \%$ for $\mathrm{P}$ at the $50 \%$ fertilizer rate $(15 \mathrm{~g} /$ plant $)$ with amount leached varying weekly due to rainfall (Million et al., 2007). Conversely, Ruter (1998) found cyclic irrigation compared with single application irrigation did not affect $\mathrm{NO}_{3}-\mathrm{N}$ quantity leached. Unlike most previous reports, we did not find that irrigation volume treatment affects $\mathrm{NO}_{3}-\mathrm{N}$ and $\mathrm{PO}_{4}-\mathrm{P}$ leached, perhaps this difference is due to how plants were irrigated in the different studies. Most previous work used one or two irrigation events per day, while our irrigation was based on plant water use, often resulting in multiple, small applications per day.

Tyler et al. (1996) reported that $\mathrm{NO}_{3}-\mathrm{N}$ quantity was less for the $50 \%$ fertilizer rate (1.75 $\mathrm{g} \mathrm{N} /$ container) than the high rate; however, $\mathrm{PO}_{4}-\mathrm{P}$ was not reduced by the $50 \%$ fertilizer rate. This supports our finding that the $25 \%$ and $50 \%$ fertilizer rates reduced leached $\mathrm{NO}_{3}-\mathrm{N}$; however, we also saw reduced leaching of $\mathrm{PO}_{4}-\mathrm{P}$ at low fertilizer rates.

Shoot growth. There was an interactive effect of fertilizer rate and irrigation treatment on shoot dry weight (Fig. 4). Shoot dry weight was lower with the $25 \%$ fertilizer rate 


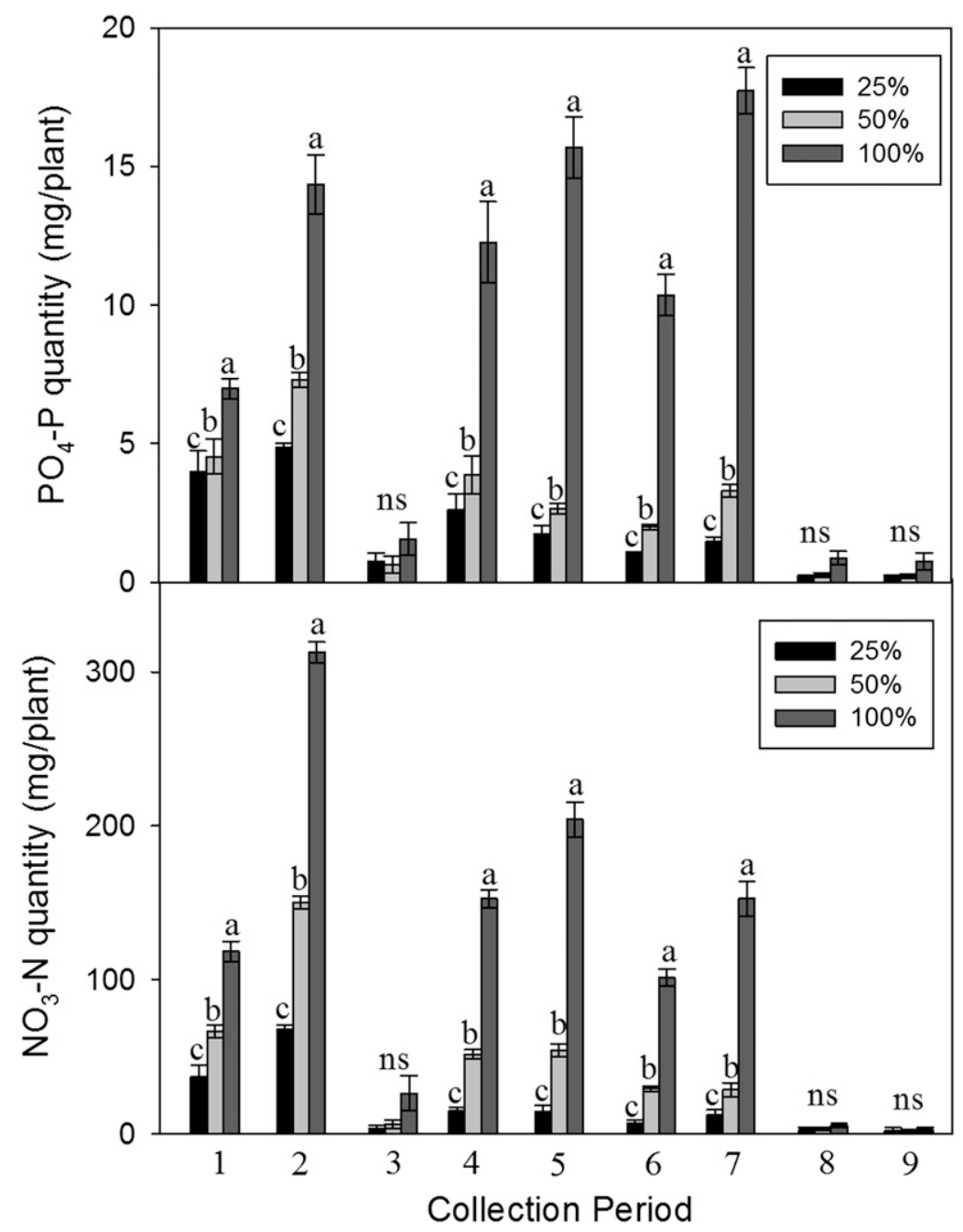

Fig. 7. Quantity of $\mathrm{NO}_{3}-\mathrm{N}$ and $\mathrm{PO}_{4}-\mathrm{P}$ leached during the nine biweekly collection periods during the production of. Gardenia jasminoides 'MAGDA I'. Irrigation was initiated for all treatments when the volumetric water content of the control (66 mL irrigation volume, $100 \%$ fertilizer rate) dropped below the $0.35 \mathrm{~m}^{3} \cdot \mathrm{m}^{-3}$ threshold. Irrigation was applied for $2,3,4$, or $5 \mathrm{~min}$, applying $66,100,132$, and $165 \mathrm{~mL}$ of irrigation water to the different treatments. Fertilizer rates were applied at $100 \%, 50 \%$, and $25 \%$ of bag rate of a controlled-release fertilizer. Means within a collection period with different letters indicate different nutrient quantities, ns indicates no fertilizer effect on nutrient quantities. Error bars indicate SES.

(18.1-19.9 $\mathrm{g} / \mathrm{plant})$ than with the $50 \%$ and $100 \%$ rates $(22.7-27.1$ and $23.8-30.4 \mathrm{~g} /$ plant, respectively) $(P<0.0001)$. Only at the $100 \%$ fertilizer rate did increasing irrigation volumes increase shoot dry weight $(P=0.02$; Fig. 4A). There was no fertilizer or irrigation treatment effect on plant height, with final height ranging from 191 to $212 \mathrm{~mm}$ (data not shown). Final growth index of plants fertilized at the $50 \%$ and $100 \%$ rates was greater than at the $25 \%$ rate $(P<0.0001$; Fig. $5 \mathrm{~B})$. There was a fertilizer rate by irrigation volume interaction, indicating that the effect of fertilizer rate on the growth index depended on the irrigation volume $(P=$ $0.0073)$. At the $50 \%$ and $100 \%$ fertilizer rates, growth index was affected by irrigation volume, but not at the $25 \%$ fertilizer rate. Compactness, calculated as shoot dry mass per unit plant height, is a measure of plant quality (van Iersel and Nemali, 2004). The $25 \%$ fertilizer rate produced less compact plants $\left(96 \mathrm{~g} \cdot \mathrm{m}^{-1}\right)$ than the $50 \%$ and $100 \%$ rates $\left(P<0.0001 ; 126\right.$ and $\left.136 \mathrm{~g} \cdot \mathrm{m}^{-1}\right)$, with no effect of irrigation volume. Similar shoot dry weight, growth index, and compactness with the $50 \%$ and $100 \%$ fertilizer rates suggests that fertilizer rate can be reduced to $50 \%$ without reducing plant size or quality.

Other researchers have found reductions in plant growth with reduced fertilizer applications. Shoot dry weight of $C$. dammeri 'Skogholm' was reduced by $26 \%$ when fertilizer rate was reduced by $50 \%$ (Tyler et al., 1996). Million et al. (2007) found that shoot dry weight of $V$. odoratissimum was reduced by $32 \%$ with a lower fertilizer rate ( 15 vs. $30 \mathrm{~g} / \mathrm{plant}$ ). Shoot dry weight of $L$. camara 'Sunny Side Up' increased from $14 \mathrm{~g}$ at $25 \%$ fertilizer rate to $35 \mathrm{~g}$ with $150 \%$ fertilizer rate (Bayer et al., 2014). Plant height of $V$. odoratissimum was $15 \%$ greater with increased fertilizer application (Million et al., 2007). Conversely, Cabrera (2003) reported shoot dry weight was reduced with increased $\mathrm{N}$ treatments over $60 \mathrm{mg} \cdot \mathrm{L}^{-1}$, indicating that increased nutrients do not always result in increased growth. The effect of irrigation volume on shoot dry weight has been variable in other research. Shoot dry weight of $C$. dammeri 'Skogholm' was reduced by $8 \%$ by maintaining a low leaching fraction (Tyler et al., 1996). Million et al. (2007) found that shoot dry weight of $V$. odoratissimum was reduced by $6 \%$ at the $2-\mathrm{cm}$ irrigation application compared with the 1-cm irrigation application. Shoot dry weight of $L$. camara 'Sunny Side Up' was unaffected by irrigation volume (Bayer et al., 2014). Plant height of $V$. odoratissimum was unaffected by irrigation volume (Million et al., 2007). The results of these studies along with this study suggest that fertilizer rate has a greater impact on aboveground growth than irrigation volume. Although many of these studies found reduced shoot dry weight with reduced fertilizer applications, irrigation applications may not have been as efficient as the method used in this study. These results suggest that decreased fertilizer rates may affect species differently, but there is potential for using reduced fertilizer rates.

\section{Conclusions}

Reduced fertilizer applications can be used with more efficient irrigation to produce salable plants with reduced nutrient leaching. Fertilizer applications at $50 \%$ of the recommended bag rate were adequate for production of $G$. jasminoides 'MAGDA I' and reduce leachate $\mathrm{EC}, \mathrm{NO} 3-\mathrm{N}$ quantities, and $\mathrm{PO}_{4}$-P quantities. Increased irrigation volume had little effect on growth. Potential benefits of using reduced fertilizer rates and lower irrigation volumes are decreased water and nutrient leaching and runoff. Further research investigating fast- vs. slow-growing species, high vs. low fertilizer requirements, and high vs. low water use would give a clearer picture of how irrigation and fertilization can be altered in a production environment to reduce inputs while producing salable plants.

\section{Literature Cited}

Bayer, A., I. Mahbub, M. Chappell, J. Ruter, and M.W. van Iersel. 2013. Water use and growth of Hibiscus acetosella 'Panama Red' grown with a soil moisture sensor-controlled irrigation system. HortScience 48:980-987.

Bayer, A., K. Whitaker, M. Chappell, J. Ruter, and M. van Iersel. 2014. Effect of irrigation duration and fertilizer rate on plant growth, substrate EC, and leaching volume. Acta Hort. (ISHS) 1034:477-484.

Beeson, R.C., Jr. 2006. Relationship of plant growth and actual evapotranspiration to irrigation frequency based on management allowed deficits for container nursery stock. J. Amer. Soc. Hort. Sci. 131:140-148.

Beeson, R.C., Jr., M.A. Arnold, T.E. Bilderback, B. Bolusky, S. Chandler, H.M. Gramling, J.D. Lea-Cox, J.R. Harris, P.J. Klinger, H.M. Mathers, J.M. Ruter, and T.H. Yeager. 2004. Strategic vision of container nursery irrigation in the next ten years. J. Environ. Hort. 22:113-115. 
Bilderback, T.E. 2002. Water management is key in reducing nutrient runoff from container nurseries. HortTechnology 12:541-544.

Burnett, S.E. and M.W. van Iersel. 2008. Morphology and irrigation efficiency of Gaura lindheimeri grown with capacitance-sensor controlled irrigation. HortScience 43:1555-1560.

Cabrera, R.I. 2003. Nitrogen balance for two container-grown woody ornamental plants. Sci. Hort. 97:297-308.

Chappell, M., J. Owen, S. White, and J. Lea-Cox. 2013a. Irrigation management practices. In: T. Yeager, T. Bilderback, D. Fare, C. Gilliam, J. Lea-Cox, A. Niemiera, J. Ruter, K. Tilt, S. Warren, T. Whitwell, and R. Wright (eds.). Best management practices: Guide for producing nursery crops. 3rd ed. Southern Nursery Association, Atlanta, GA.

Chappell, M., S.K. Dove, M.W. van Iersel, P.A. Thomas, and J. Ruter. 2013b. Implementation of wireless sensor networks for irrigation control in three container nurseries. HortTechnology 23:747-753.

Fare, D.C., C.H. Gilliam, and G.J. Keever. 1992. Monitoring irrigation at container nurseries. HortTechnology 2:75-78.

Fare, D.C., C.H. Gilliam, G.J. Keever, and J.W. Olive. 1994. Cyclic irrigation reduces container leachate nitrate-nitrogen concentration. HortScience 29:1514-1517.

Hilhorst, M.A. 2000. A pore water conductivity sensor. Soil Sci. Soc. Amer. J. 64:1922-1925.

Kohanbash, D., G. Kantor, T. Martin, and L. Crawford. 2013. Wireless sensor network design for monitoring and irrigation control: User-centric hardware and software development. HortTechnology 23:725-734.

Lea-Cox, J.D. and D.S. Ross. 2001. A review of the federal clean water act and the Maryland water quality improvement act: The rationale for developing a water and nutrient management planning process for container nursery and greenhouse operations. J. Environ. Hort. 19:226-229.

Lea-Cox, J.D., W.L. Bauerle, M.W. van Iersel, G. F. Kantor, T.L. Bauerle, E. Lichtenberg, D.M. King, and L. Crawford. 2013. Advancing wireless sensor networks for irrigation management of ornamental crops: An overview. HortTechnology 23:717-724.

Martin, C.A. and D.L. Ingram. 1991. Evaluation of thermal properties and effect of irrigation on temperature dynamics in container media. $\mathrm{J}$. Environ. Hort. 9:24-28.

Million, J., T. Yeager, and J. Albano. 2007. Consequences of excessive overhead irrigation on runoff during container production of sweet viburnum. J. Environ. Hort 25:117-125.

Nemali, K.S., F. Montesano, S.K. Dove, and M.W. van Iersel. 2007. Calibration and performance of moisture sensors in soilless substrates: $\mathrm{ECH}_{2} \mathrm{O}$ and Theta probes. Sci. Hort. 112:227-234.

Nemali, K.S. and M.W. van Iersel. 2006. An automated system for controlling drought stress and irrigation in potted plants. Sci. Hort. 110:292-297.

Niemiera, A.X. and C.E. Leda.1993. Nitrogen leaching from Osmocote-fertilized pine park at leaching fractions of 0 to 0.4. J. Environ. Hort 11:75-77.

O'Meara, L., M.R. Chappell, and M.W. van Iersel. 2014. Water use of Hydrangea macrophylla and Gardenia jasminoides in response to a gradually drying substrate. HortScience 49:493-498.

Owen, J.S., Jr., S.L. Warren, T.E. Bilderback, and J.P. Albano. 2008. Phosphorus rate, leaching fraction, and substrate influence on influent quantity, effluent nutrient content, and response of a containerized woody ornamental crop. HortScience 43:906-912.

Ruter, J.M. 1993. Growth and landscape performance of three landscape plants produced in conventional and pot-in-pot production systems. J. Environ. Hort. 11:124-127.
Ruter, J.M. 1998. Pot-in-pot production and cyclic irrigation influence growth and irrigation efficiency of 'Okame' cherries. J. Environ. Hort. 16:159-162.

Scoggins, H.L. and M.W. van Iersel. 2006. In situ probes for measurement of EC of soilless substrates: Effects of temperature and substrate moisture content. HortScience 41:210 214.

Tyler, H.H., S.L. Warren, and T.E. Bilderback. 1996. Reduced leaching fractions improve irrigation use efficiency and nutrient efficacy. J. Environ. Hort. 14:199-204.

U.S. Environmental Protection Agency. 1983. Phosphorus, all forms. Method 365.1 (Colorimetric, Automated, Ascorbic Acid). p. 365-1.1365-1.7. In: Methods for chemical analysis of water and wastes, EPA-600/4-79-020. U.S. E.P.A., Cincinnati, OH.

van Iersel, M.W. and K.S. Nemali. 2004. Drought stress can produce small but not compact marigolds. HortScience 39:1298-1301.

van Iersel, M.W., R.M. Seymour, M. Chappell, F. Watson, and S. Dove. 2009. Soil moisture sensor-based irrigation reduces water use and nutrient leaching in a commercial nursery. Proc. Southern Nursery Assn. 54:17-21.

van Iersel, M.W., M. Chappell, and J.D. Lea-Cox. 2013. Sensors for improved efficiency of irrigation in greenhouse and nursery production. HortTechnology 23:735-746.

Warsaw, A.L., R.T. Fernandez, B.M. Cregg, and J. A. Andresen. 2009. Container-grown ornamental plant growth and water runoff nutrient content and volume under four irrigation treatments. HortScience 44:1573-1580.

Yeager, T., J. Million, C. Larsen, and B. Stamps. 2010. Florida nursery best management practices: Past, present, and future. HortTechnology 20:82-88. 